EPiC Series in Biological Sciences
Volume 1, 2021, Pages 133-142
$\begin{gathered}\text { Proceedings of KOBI 2nd International Confer- } \\ \text { ence on Management of Tropical Biodiversity for } \\ \text { Human Welfare: From Ecosystem to Molecular }\end{gathered}$

\title{
Analysis of Stomatal Number and Size in Six Species of Monocotiledon Plants
}

\author{
Sunarseh ${ }^{1}$ and Entin Daningsih ${ }^{1 *}$ \\ ${ }^{1}$ University of Tanjungpura, Pontianak, Indonesia \\ entin.daningsihefkip.untan.ac.id
}

\begin{abstract}
The benefits of ornamental plants are not only for aesthetic values but also for cooling down its environmental temperature. This cooling effect is due to the transpiration rate. The transpiration rate is influenced by the stomatal number and size. This study aimed to measure the stomatal number and size of monocotyledon plants. The method used factorial Completely Randomized Design (CRD). The main treatment factors were six monocotyledon plant species and three plant parts namely top, middle, and bottom plant parts, and a combination of the treatments was between the two with five replications. The data were analyzed using SAS with the model of factorial CRD and if the treatments were significant it was followed by LSD test. Plant species, plant parts, and the combination between the two significantly influenced on stomatal number and size. Cordyline fruticosa had the highest stomata number (340) significantly compared to others while Rhoeo discolor had the lowest one (30). However, Rhoeo discolor had the largest stomatal size $(2285,7 \mu \mathrm{m})$ significantly compared to others while Cordyline fruticosa had the smallest $(114,1 \mu \mathrm{m})$. Top plant parts had the highest stomatal number (172) significantly compared to the middle (141) and bottom parts (138). The stomatal number correlated inversely with stomatal size both in plant species and plant parts.
\end{abstract}

\section{Introduction}

Stomata are gaps in which modification of epidermal tissue playing a role in regulating the entry and exit of air and water vapor in the leaf. Air and water regulation are carried out by a pair of guard cells of stomata that have pores between the two cells. The size of the pores is regulated by the mechanism of changing the shape of the guard cell and is always actively working, except when the plant is dehydrated (Retno, 2015). The stomata consist of guard cells and neighboring cells. Stomata are generally found on the lower surface of a leaf but there are several plant species where stomata can be found on both leaves. Some plants only have stomata on both surfaces of the leaves (Lakitan, 2007). It is also a form of adaptation to the environment which aims to reduce transpiration (Campbell, 2003). Stomata in each species of plant have different numbers and sizes. Haryanti (2010) found that the 
number of stomata in dicotyledons and monocotyledons plants varied in each plant species.

According to Tambaru (2013) stomatal size related to the stomatal number on plant leaves. If the size of the stomata is small, the number of stomata found on the leaves is high, whereas if the stomata are large, the number of stomata on the leaves is low. The number of stomata is strongly influenced by the species of plant itself (genetic factor) (Tambaru, 2013); however, Juariah (2014) states that each species of plant had a different number and size, which is related to the indication of the plant's response to extreme environmental conditions, such as the availability of water and nutrients, to maintain its physiological functions, for example, photosynthesis and transpiration in the leaves (environmental factors). Tanugrah (2016) working on several ornamental and shading plants found that the number of plant stomata varied and found Rhoe discolor had the lowest number of stomata (49 stomata). Further research was conducted to find stomatal size and type by Vivin (2017) and found Rhoe discolor had the longest stomatal size that was $74.44 \mu \mathrm{m}$ and the widest was $42.08 \mu \mathrm{m}$. Rhoe discolor was one plant species used in the current research.

The opening of stomata is related to plant metabolic processes, namely transpiration and photosynthesis. Stomata play a role in $\mathrm{CO}_{2}$ diffusion in photosynthesis. In addition, the stomata also function as water vapor exit from cells in the process of transpiration (Salisbury and Ross, 1995). The opening stomata also vary in the morning and evening in a species. This difference also occurs among species (Juariyah, 2014; Hidayat, 1995). Stomata opening can be influenced by environmental factors, including light intensity, temperature, and water. These environmental factors can change over time (morning, afternoon, and evening). Stomata in the morning will start to open wide because the light intensity and temperature are not too high and enough humidity causing guard cells turgidity. But the stomata during the day will close because of the high intensity of light and temperature and excessive evaporation (Hopkins, 2004). This is exemplified by the opening of weed stomata Melastoma malabatthricum L. which opens wide at the time range 09.00-10.00 (Fatonah, 2011). Al, Suryani, and Ratnawati (2003) found more stomata in young leaves than adult leaves, and at lowest was on old leaves. This was due to the development of leaves where epidermal cells in old leaves have developed more optimally causing larger leaf sizes so the number of stomata in the same field of view becoming larger but there were few in numbers. This was also shown in Angsana leaves aging between 15 days and 20 days (Yuda, 2013). On leaves of 15 days, the number of stomata was found more than in the leaves that age 20 days old. Thus, the development of leaf age affects the number and size of the stomata. This current research was conducted to know the effects of plant species, plant parts, combination treatments namely species and part of the plants on the number and size of stomata on six species of monocotyledons plants which are often used as ornamental plants in Pontianak, and to find out the relationship between the number and size of stomata.

\section{Materials and Methods}

This study used Factorial Completely Randomized Design (Factorial CRD) with the main factors namely six plant species (Rhoeo discolor Hance, Cordyline fruticosa A. Chev, Chlorophytum comosum (Thunb) Jacq., Dracaena reflexa Lam., Aglaonema crispum (Pit. \& Man.), and Crynum asiaticum L.) and the leaves from three different plant parts (top, middle and bottom) and the treatment combinations were between plant species and plant parts.

The preparation stage started from replanting six species of monocotyledon plants that had a similar size in three $\mathrm{kg}$ volume of polybags. Plants were transferred to pots with planting media of soil and sand with a ratio of 2:1. Each plant consisted of 5 replications. Stomatal slide using the replica method was carried out in the time range between 09:00 and 10:00 am to optimize the opening of stomata (Fatonah, 2013). The procedure for the replica stomatal slide refers to Hartyanti (2010). 
The procedure for calculating the number of stomata refers to Haryanti (2010) with a modification of 10 x 10 magnification. Haryanti (2010) categorized the stomatal number into five groups namely: few (1-50), quite a few (51-100), many (101-201), many more (> 201), and infinite (> 300).

Measurements of the length and the width of the stomata were carried out using an Olympus CX21 microscope equipped with an ocular micrometer that had been calibrated (Hidayanti, 2009). The measurement of stomata length refers to Juariyah (2014) while the measurement of stomatal width refers to Vivin (2017), Utami (2017), Mustika, (2017) with modification of 10 x 40 magnification.

Stomata are generally like the form of the elliptical field (Meidner and Mansfield, 1968). Calculation of elliptical wide area used the formula:

Elliptical wide area $=\pi \times$ a x b ........ (Eberly, 2016)

where $\pi=3.14, \mathrm{a}=$ radius length, and $\mathrm{b}=$ radius width. This formula was adapted into the stomata area calculation (Fikri, 2018).

The data of stomatal number and size were analyzed using SAS with Factorial Completely Randomized Design (Factorial CRD). If the results showed a significant treatment effect then proceeded with the Least Square Difference test (LSD). In addition, a correlation between the number and size of the stomata was carried out. Correlation can be positive, negative, or no relationship at all. According to Sugiyono (2015) the interpretation of the correlation coefficient is divided into five: very low $(0.00$ $0.199)$, low (0.20-0.399), medium (0.40-0.599), strong (0.60-0.799) and very strong $(0.80-1,000)$.

\section{Results and Discussion}

Stomata can be found on both sides of the leaf (amphistomatic leaves) or only on one side, the upper surface (epistomatic leaves), or more commonly found on the lower surface (hypostomatic leaves) (Kirkham, 2014; Panawala, 2017). Observations of the replica stomata slides showed Cordyline fruticosa A. Chev, Chlorophytum comosum (Thunb) Jacq., Dracaena reflexa Lam., Aglaonema crispum (Pit. \& Man.) and Crynum asiaticum L. had stomata on both sides (amphistomatic) whereas Rhoe discolor Hance had stomata on the lower surface (hypostomatic) (Figure 1). This is in line with Tanugrah (2016) that Rhoeo discolor Hance only had stomata on the lower surface of the leaf. The number of stomata in the six species of monocotyledon plants ranged from 30-340 stomata (Table 1). The number of stomata in Rhoeo discolor Hance was in a few categories (30 stomata) that in line with Tanugrah's (2016) study which found that the Rhoeo discolor Hance plant had few categories of stomata (49 stomata). Haryanti (2010) found the number of Rhoeo discolor Hance stomata had few number categories. The stomata number of Aglaonema crispum (Pit. \& Man.) was included in quite a few categories (73 stomata) whereas Crynum asiaticum L. and Chlorophytum comosum (Thunb) were included many categories (145 and 131 stomata respectively). The stomata number of Cordyline fruticosa A. Chev was included in the infinite category (340 stomata). This was in line with Vinly (2016) that Cordyline fruticosa A. Chev had an infinite number of stomata category (313 stomata) supported by Istiqomah (2016) who also found that Cordyline fruticosa A. Chev had an infinite number of stomata category (439 stomata). The differences in the stomata number can be influenced by genetic factors (Zhang, 2018) and environmental factors (Lakitan, 2011). 


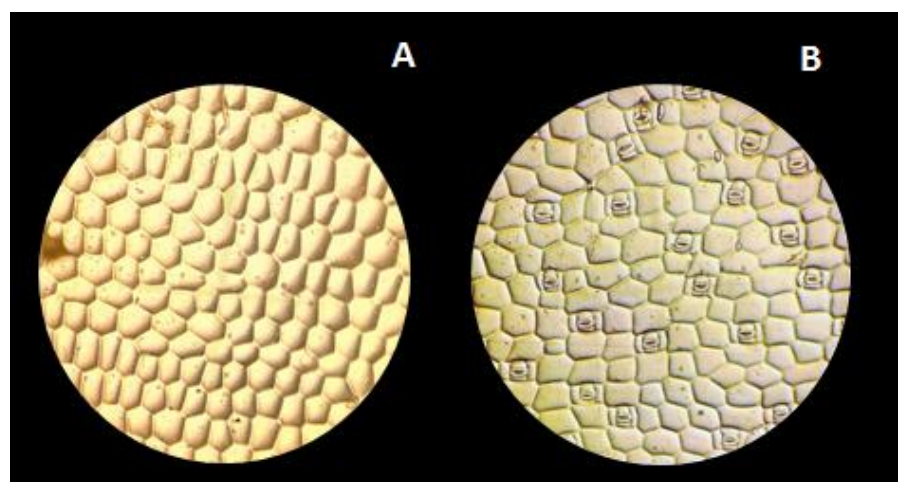

Figure 1: Observation of the number of Rhoeo discolor Hance stomata using a microscope with a magnification of $10 \times 10$. (A) upper surface (B) lower surface.

\begin{tabular}{lcc}
\hline \multicolumn{1}{c}{ Plants } & $\begin{array}{c}\text { Number of } \\
\text { Stomata }\end{array}$ & Categories \\
\hline Cordyline fruticosa A. Chev & 340 & Infinity \\
Crynum asiaticum L. & 184 & Many \\
Chlorophytum comosum (Thunb) Jacq. & 145 & Many \\
Dracaena reflexa Lam. & 131 & Many \\
Aglaonema crispum (Pit. \& Man.) & 73 & Enough \\
Rhoeo discolor Hance & 30 & Little \\
\hline
\end{tabular}

Table 1: The number and category of stomata in six species of monocotyledon plants

Based on the results of ANOVA analysis, plant species, plant parts, and combinations of plant species and plant parts had significant influences $(\mathrm{P}=0.0001)$ on stomata number $($ Table 2$)$.

\begin{tabular}{lcc}
\hline \multicolumn{1}{c}{ Variable } & $\begin{array}{c}\text { Number of } \\
\text { Stomata }\end{array}$ & Significance \\
\hline Plant species & & $* * *$ \\
Cordyline fruticosa A. Chev & $340^{\mathrm{a}}$ & \\
Crynum asiaticum L. & $184^{\mathrm{b}}$ & \\
Chlorophytum comosum (Thunb) Jacq.) & $145^{\mathrm{c}}$ & \\
Dracaena reflexa Lam. & $131^{\mathrm{c}}$ & \\
Aglaonema crispum (Pit. \& Man.) & $73^{\mathrm{d}}$ & \\
Rhoeo discolor Hance & $30^{\mathrm{e}}$ & $* * *$ \\
Plant parts & & \\
Top & $172^{\mathrm{a}}$ & \\
Middle & $141^{\mathrm{b}}$ & \\
Bottom & $138^{\mathrm{b}}$ & \\
Combination of plant species and plant parts & & \\
Cordyline fruticosa A. Chev * top & $418^{\mathrm{a}}$ & \\
Cordyline fruticosa A. Chev * middle & $311^{\mathrm{b}}$ & \\
Cordyline fruticosa A. Chev * bottom & $289^{\mathrm{c}}$ & \\
Crynum asiaticum L. top & $212^{\mathrm{d}}$ & \\
Crynum asiaticum L. $*$ middle & $183^{\mathrm{e}}$ & \\
& &
\end{tabular}




$\begin{array}{lc}\text { Crynum asiaticum } \text { L. } * \text { bottom } & 156^{\mathrm{f}} \\ \text { Chlorophytum comosum } \text { (Thunb) Jacq.) * top } & 150^{\mathrm{f}} \\ \text { Chlorophytum comosum } \text { (Thunb) Jacq.)* middle } & 146^{\mathrm{f}} \\ \text { Chlorophytum comosum } \text { (Thunb) Jacq.) * bottom } & 140^{\mathrm{f}} \\ \text { Dracaena reflexa } \text { Lam. * top } & 136^{\mathrm{f}} \\ \text { Dracaena reflexa } \text { Lam. * middle } & 131^{\mathrm{f}} \\ \text { Dracaena reflexa } \text { Lam. * bottom } & 127^{\mathrm{g}} \\ \text { Aglaonema crispum } \text { (Pit. \& Man.)* top } & 83^{\mathrm{g}} \\ \text { Aglaonema crispum } \text { (Pit. \& Man.)* middle } & 70^{\mathrm{g}} \\ \text { Aglaonema crispum } \text { (Pit. \& Man.)* bottom } & 67^{\mathrm{g}} \\ \text { Rhoeo discolor } \text { Hance * top } & 34^{\mathrm{h}} \\ \text { Rhoeo discolor Hance * middle } & 30^{\mathrm{h}} \\ \text { Rhoeo discolor } \text { Hance * bottom } & 26^{\mathrm{h}}\end{array}$

$156^{\mathrm{f}}$

$150^{\mathrm{f}}$

$146^{\mathrm{f}}$

$140^{\mathrm{f}}$

$136^{\mathrm{f}}$

$131^{\mathrm{f}}$

$127^{\mathrm{g}}$

$83^{\mathrm{g}}$

$70^{\mathrm{g}}$

$67^{\mathrm{g}}$

$34^{\mathrm{h}}$

$26^{\mathrm{h}}$

Table 2: The results of the variance analysis of stomata number on monocotyledons plants

$* * *=$ highly significant at $\alpha=0.001$, different letters behind the mean within the same column were significantly different when tested with LSD at $\alpha=0.05$.

The LSD test results showed that Cordyline fruticose. A. Chev had significantly the highest number of stomata (340 stomata) and significantly different from other plant species, while Rhoeo discolor Hance had the lowest number of stomata (30) and significantly different from other plant species (Table 2). The number of stomata varies on the same plant leaves (Hidayat, 1995). According to Zhang et al (2012), differences in the number of stomata can be influenced by genetic and environmental factors. The number of stomata in Thalictrum alpinum was more influence by environmental factors while the number of stomata in Kobresia humilis was more influenced by genetic factors. The difference in the number of stomata may be caused by environmental factors such as light, air humidity, water availability, and $\mathrm{CO}_{2}$ concentration. In this current research, the environmental factors were similar, indicating the difference of stomata number in plant species in monocotyledon plants was due to genetic factors.

Based on three parts of the plant showed the leaves from the top part had the significantly highest number of stomata (172 stomata) and significantly different from the leaves from the middle and bottom parts. The leaves from the bottom part had the lowest stomata number (138 stomata) but not significantly different from the number of stomata in the middle (141 stomata). According to $\mathrm{Al}$, Suryani, and Ratnawati (2003) stomata were more commonly found in young leaves than adult leaves and were lowest on old leaves. This was due to the development of leaves where the epidermal cells in the old leaves had developed optimally which caused the size of the leaves to enlarge so that the number of stomata in the same field of view became larger but the number getting few. Yudha, Noli, and Idris (2013) showed that the density of stomata on Angsana leaves reduces from the leaves aging 15 days to 20 days old. In addition, Hidayat (1995) also stated that the stomata began to develop before meristematic activity in the epidermis and continue to develop for some time, while the leaves were elongated and expanded and continue to develop due to the cell enlargement.

The combination of plant species and plant parts showed that Cordyline fruticosa A. Chev with a combination of 3 parts of plants had the highest stomata number. All the combinations between Cordyline fruticosa A. Chev with three other plant parts showed the highest stomata number that was compared to the other combinations. Meanwhile, the stomata number of Rhoe discolor combine to other parts of the plant showed the lowest stomata number significantly (Table 2). The stomata number of any combination between plant species and plant parts were consecutively from Cordyline fruticosa A. Chev, Crynum asiaticum L., Chlorophytum comosum (Thunb) Jacq., Dracaena reflexa Lam., Aglaonema crispum (Pit. \& Man.), and Rhoeo discolor Hance. 


\begin{tabular}{|c|c|c|}
\hline Variable & $\begin{array}{c}\text { Area of } \\
\text { stomata }(\mu \mathrm{m}) \\
\end{array}$ & Significance \\
\hline Plant species & & **** \\
\hline Rhoeo discolor Hance & $2285,7^{\mathrm{a}}$ & \\
\hline Crynum asiaticum $\mathrm{L}$. & $1708,6^{\mathrm{b}}$ & \\
\hline Aglaonema crispum (Pit. \& Man.) & $1449,5^{\mathrm{c}}$ & \\
\hline Dracaena reflexa Lam. & $504,6^{\mathrm{d}}$ & \\
\hline Chlorophytum comosum (Thunb) Jacq. & $407,2^{\mathrm{d}}$ & \\
\hline Cordyline fruticosa A. Chev & $114,1^{\mathrm{e}}$ & \\
\hline Plant parts & & $* * *$ \\
\hline Upper & $897,72^{b}$ & \\
\hline Middle & $1107,52^{\mathrm{a}}$ & \\
\hline Under & $1229,60^{\mathrm{a}}$ & \\
\hline Combination of plant species and plant parts & & $* *$ \\
\hline Rhoeo discolor Hance * Upper & $2638,58^{\mathrm{a}}$ & \\
\hline Rhoeo discolor Hance * Middle & $2308,88^{b}$ & \\
\hline Crynum asiaticum L.* Under & $2055,23^{\mathrm{c}}$ & \\
\hline Rhoeo discolor Hance * Upper & $1909,51^{\mathrm{c}}$ & \\
\hline Crynum asiaticum $\mathrm{L} . *$ Middle & $1864,67^{\mathrm{c}}$ & \\
\hline Aglaonema crispum (Pit. \& Man.)* Under & $1611,70^{\mathrm{d}}$ & \\
\hline Aglaonema crispum (Pit. \& Man.)* Upper & $1433,73^{\mathrm{e}}$ & \\
\hline Aglaonema crispum (Pit. \& Man.)* Middle & $1303,10^{\mathrm{e}}$ & \\
\hline Crynum asiaticum $\mathrm{L} . *$ Under & $1205,96^{\mathrm{e}}$ & \\
\hline Dracaena reflexa Lam.* Upper & $533,30^{\mathrm{f}}$ & \\
\hline Dracaena reflexa Lam.* Middle & $512,85^{\mathrm{g}}$ & \\
\hline Dracaena reflexa Lam. * Under & $467,57^{\mathrm{g}}$ & \\
\hline Chlorophytum comosum (Thunb) Jacq.* Upper & $418,06^{\mathrm{g}}$ & \\
\hline Chlorophytum comosum (Thunb) Jacq.* Middle & $412,03^{\mathrm{g}}$ & \\
\hline Chlorophytum comosum (Thunb) Jacq.* Under & $391,52^{\mathrm{g}}$ & \\
\hline Cordyline fruticosa A. Chev * Upper & $120,69^{\mathrm{h}}$ & \\
\hline Cordyline fruticosa $\mathrm{A}$. Chev * Middle & $112,94^{\mathrm{h}}$ & \\
\hline Cordyline fruticosa A. Chev * Under & $108,67^{\mathrm{h}}$ & \\
\hline
\end{tabular}

Table 3: The results of the variance analysis of the stomata area on monocotyledon plants.

$* *=$ significance at $\alpha=0.01 * * *=$ highly significant at $\alpha=0.001$ different letters behind the mean within the same column were significantly different when tested with LSD at $\alpha=0.05$.

Based on the results of ANOVA, plant species, plant parts, and combinations between the two had significantly influenced the area of the stomata. Based on the plant species, Rhoeo discolor Hance had the largest area $(2,285.7 \mu \mathrm{m})$ (table 3$)$ followed by Crynum asiaticum L. $(1,708.6 \mu \mathrm{m})$ and Aglaonema crispum (Pit. \& Man.) $(1,449.5 \mu \mathrm{m})$. However, the three of these plant species were significantly different from one to the other. Meanwhile Dracaena reflexa Lam. and Chlorophytum comosum (Thunb) Jacq. $(407,2 \mu \mathrm{m})$ were smaller areas significantly from the other three plant species before. But the two of these plants were not significantly different from each other. Finally, Cordyline fruticosa A. Chev $(144.1 \mu \mathrm{m})$ had the smallest are of stomata significantly compared to the other plant species. The largest and smallest area of stomata can be seen in Figure 2. 


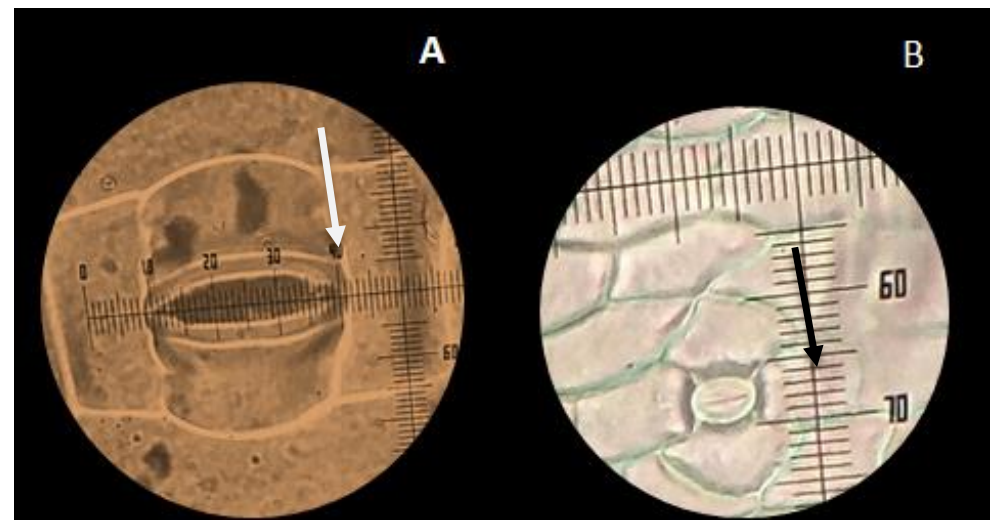

Figure 2: Observation of the stomata area using microscope $10 \times 40$ magnification. (A) Rhoeo discolor Hance (B) Cordyline fruticosa A. Chev.

The stomata area was inversely proportional to the number of stomata. This can be seen from Rhoeo discolor Hance which had the fewest number of stomata (30) and had the largest area $(2,285.7 \mu \mathrm{m})$ while Cordyline fruticosa A. Chev had the highest number of stomata (340) and had the smallest area $(114.1 \mu \mathrm{m})$. This was consistent with Tambaru (2013) who revealed that the size of the stomata was inversely proportional to the number of stomata on the leaves of the plant. If the size of the stomata is small, the number of stomata found on the leaves is high whereas if the stomata are large, the number of stomata on the leaves was few. According to Camargo and Marenco (2011), the number of stomata reverses with/to the size of the stomata in 35 tree species in the Amazon forest.

The opening of the stomata also varied in the morning and evening in a plant species; these differences also occurred between species (Juariyah, 2014; Hidayat, 1995). Stomata opening can be influenced by environmental factors including light intensity, temperature, and water. These environmental factors can change over time (morning, afternoon, and evening). Stomata in the morning will start to open wide because the light intensity and temperature are not too high and humidity is enough causing guard cells turgidity to increase. But the stomata during the day will close because of the high intensity of light and temperature and excessive evaporation (Hopkins, 2004). This was exemplified by the opening of weed stomata of Melastoma malabatthricum $\mathrm{L}$. which opens wide at the time range between $09.00 \mathrm{am}$ and $10.00 \mathrm{am}$ (Fatonah, 2011). In this current research, the experiment was conducted between 09.00 and 10.00 am to facilitate the wide opening of stomata. The experiment was also conducted under the similar bright sun, low wind speed, and temperature.

According to Casson and Gray (2007), stomata in the epidermis of adult leaves were usually separated from each other by at least one epidermal cell to ensure optimal stomata function. If the stomata are too tight it would affect the size of the stomata to become smaller. The change in the size of the stomata followed by changes in the density of the stomata was thought to be closely related to the important function of the stomata in photosynthesis and transpiration. Based on the ANOVA results, Rhoe discolor had the lowest number of stomata (Table 2) but had the biggest size of stomata (Table 3 and Figure 2a) amongst the other monocotyledons plants. On the other hand, Cordyline fruticosa A. Chev had the highest number of stomata (Table 2) but the smallest size of stomata (Table 3 and Figure 2b). This was similar to the finding of Casson and Gray (2007). However, despite the differences between stomatal number and size for Rhoe discolor Hance and Cordyline fruticosa A. Chev, both plant species had transpiration rates similarly (Cahyati, 2018). The combination of stomatal size and number allowed the plant to transpired equally. Although in another study showed that the higher number of stomata and the smallest area of stomata will be produced by the plant which adapted in the arid area (Silva et al, 2014). Dense small stomata can quickly adapt to changes in the environment (Hong et al., 2018). With these findings by Silva (2014), it would indicate that Cordyline fruticosa A. Chev having 
the highest number of stomata adapted more to the arid environment. However further research is needed to prove it.

The results of the stomata area on the leaves from three plant parts of six species of monocotyledon plants (Table 3 ) showed that the top part stomata had the significantly smallest area $(897.72 \mu \mathrm{m})$ and significantly different from the middle and bottom parts. While the stomata area from the middle part $(1107.52 \mu \mathrm{m})$ and the bottom part $(1229.60 \mu \mathrm{m})$ had a stomata area that was not significantly different from one to another. The stomata area on plant parts was also inversely proportional to the number of plant stomata where the top part of the plant had the highest number of somata (172), the top part had the smallest stomata area $(897.72 \mu \mathrm{m})$. The differences of the stomata area were not only influenced by plant species and plant parts but also a combination of plant species and plant parts. The optimum opening size of stomata which determines each area is thought by influx from epidermal cell to guard cell of stomata or acidity changing due to photosynthesis (Salisbury, 1995). Meanwhile, the number of stomata was already set genetically (Zhang et al, 2012). On the leaves in the top part of the plant leaf sizes were still small and indicated young age whilst the leaves from the bottom part were already adult age so that the leaf expanded due to cell enlargement cause the view of stomatal and epidermal cell numbers fewer within the same area. Yudha et al (2013) showed the numbers of stomata on the laves aging fifteen days were fewer compared to those of the leaves at the age of five days. The development of plant leaves according to the age resulted in a bigger size of stomata. With these two conditions related to the current research (Table 2 and Table 3), the leaves from the bottom part would result in a higher transpiration rate. In some studies, young leaves transpired a lot more than adult leaves (Salisburry, 1995 \& Cechin et al, 2010) to produce more energy to support plant cell development. However, Drake et al (2013) showed that leaves with the smallest size and highest number of stomata tend to increase gas exchange with regards to water use to raise photosynthesis. Silva et al (2014) mentioned the increase of stomata number and the smaller size of stomata caused the plant to adapt in the arid environment. These two types of research conducted by Drake et al (2013) and Silva et al (2014) synchronized to each other about the importance of smaller size and a higher number of stomata for photosynthesis and transpiration. In another study (Cahyati, 2018) showed that adult leaves transpired higher compared to the young leaves. Related to the current research the leaves from the bottom parts of the plant had a bigger size of stomata. This indicated a wider size of stomata will allow water favor to exceed from the stomata porous. Silva et al (2014) also showed the plant that planted with enough water had a bigger size of the stomata and fewer stomata. The possibility of the adult leaves to transpire higher due to the wider size and fewer number of stomata because the adult leaves had more chlorophyll content for photosynthesis. The plants, therefore, will balance between transpiration and photosynthesis.

Based on the results of research on the number and area of stomata that have been done, a correlation was conducted to determine the relationship between the number of stomata and the stomata area. Correlation analysis on six species of monocotyledon plants had a direction of negative correlation (-0.694) that was included in a strong category. Haryanti (2010) mentioned that the number of stomata could affect the rate of transpiration in the leaves. In addition, Izza and Laily (2015) stated that the number of stomata was closely related to transpiration activity because most of the transpiration was released through stomata. From the current research Cordyline fruticosa A. Chev can be adapted more to the arid environment.

\section{Acknowledgment}

This research is part of the group stomata research which began in 2016 and was funded independently. 


\section{References}

Al S, Suryani D, and Ratnawati (2013). Tanggapan Stomata dan Laju Transpirasi Daun Vaccinium varingiaefolium (BL.) Miq. menurut Tingkat Perkembangan Daun dan Jarak terhadap Sumber Emisi Gas Belerang Kawah Sikidang Dataran Tinggi Dieng. In Bahasa. Seminar Hasil Penelitian MIPA, FMIPA UNY.

Cahyati HN. (2018). Kelayakan Media Buku Saku Submateri Struktur dan Fungsi Jaringan Tumbuhan Kelas XI SMA berdasarkan Transpirasi pada Enam Jenis Tanaman Monokotil. (Skripsi). In Bahasa. Pontianak: Kalimantan Barat.

Drake PL, Froend RH \& Franks PJ. (2013). Smaller, Faster Stomata: Scaling of Stomatal Size, Rate of Response, and Stomatal Conductance. Journal of Experimental Botany. 64(2): 495-505.

Eberly D. (2008). The Area of Intersecting Ellipses. The United States of America. Geometric Tools Redmond WA 98052.

Fatonah S, Asih D, Mulyanti D, and Iriani D. (2013). Penentuan Waktu Pembukaan Stomata pada Gulma Melastoma malabathricum L. di Perkebunan Gambir Kampar, Riau. In Bahasa. Biospecies. 6 (2): $15-22$.

Haryanti S. (2010). Jumlah dan Distribusi Stomata pada Daun Beberapa Spesies Tanaman Dikotil dan Monokotil. Buletin Anatomi dan Fisiologi. 18 (2). Page number?

Hidayat EB. (1995). Anatomi Tumbuhan Berbiji. In Bahasa. Bandung: Institut Teknologi Bandung.

Istiqomah, G. (2016). Pembuatan Multimedia Interaktif Anatomi Daun Kelas XI SMA Berdasarkan Analisis Jumlah Stomata dan Kadar Klorofil Tumbuhan di Jalan Tanjungpura dan Imam Bonjol. In Bahasa. Skripsi. Pontianak: FKIP Universitas Tanjungpura.

Izza F. and Laily AN. (2015). Karakteristik Stomata Tempuyung (Sonchus arvvensis L.) dan Hubungan dengan Transpirasi Tanaman di Universitas Islam Negeri (UIN) Maulana Malik Ibrahim

Malang. In Bahasa. Seminar Nasional Konservasi dan Pemanfaatan Sumber Daya Alam.

Juairiah L. (2014). Studi Karakteristik Stomata Beberapa Jenis Tanaman Revegetasi di Lahan Pasca penambangan Timah di Bangka. In Bahasa. Widyariset. 17 (2): 213-218.

Lakitan B. (2012). Dasar-Dasar Fisiologi Tumbuhan. In Bahasa. Jakarta: PT Raja Grafindo Persada.

Nugroho H, Purnomo, and Sumardi I. (2012). Struktur \& Perkembangan Tumbuhan. In Bahasa. Jakarta: Penebar Swadaya.

Palasciano M, Camposeo S, and Godini A. (2005). Stomatal Size and Frequency in Wild (A. webbii) and Cultivated (A. communis) Almonds. Cheam Options Méditerranéennes. 63: 305-310.

Papuang N. (2014). Jumlah dan Distribusi Stomata pada Tanaman Penghijau di Kota Ternate. In Bahasa. Jurnal Bioedukasi. 2(1): 287-292.

Silva H, Sagardia S, Ortiz N, Franck N, Opazo M, Quiroz M, Baginsky C, and Tapia C. (2014) Relationships Between Leaf Anatomy, Morphology, and Water Use Efficiency in Aloe vera (L) Burm f. as a Function of Water Availability. Revista Chilena de Historia Natural. 87(13): 1-10.

Tambaru E, Latunra AI, and Suhadiyah S. Peranan Morfologi dan Tipe Stomata dalam Mengabsoropsi Karbon dioksida pada Pohon Hutan Kota UNHAS Makassar. In Bahasa. Proceedings Simposium Nasional Kimia Bahan Alam XII:12-17.

Tanugrah N. (2016). Pembuatan Komik Pencemaran Udara Kelas VII SMP Berdasarkan Analisis Jumlah Stomata dan Kadar Klorofil Tanaman di Sepanjang Jalan Ahmad Yani. (Skripsi, In Bahasa). Pontianak: Universitas Tanjungpura.

Vinly BWC. (2016). Pembuatan Video Flash Submateri Pencemaran Udara Kelas X berdasarkan Hasil Analisis Jumlah Stomata dan Kadar Klorofil Tumbuhan di Jalan Alianyang. (Skripsi, In Bahasa). Pontianak: Universitas Tanjungpura.

Vivin K D. (2017). Kelayakan Powerpoint Interaktif Organ Tumbuhan Kelas XI SMA Berdasarkan Analisis Ukuran dan Tipe Stomata Tanaman di kota Pontianak. (Skripsi, In Bahasa). Pontianak: Universitas Tanjungpura. 
Analysis of Stomatal Number and Size in Six Species of Monocotiledon ... Sunarseh and Daningsih

Yudha GP, Noli ZA, and Idris M. (2013). Pertumbuhan Daun Angsana (Pterocarpus indicus Willd) dan Akumulasi Logam Timbal (Pb). In Bahasa. Jurnal Biologi Universitas Andalas (J. Bio. UA.) 2 (2): 83-99.

Zhang L, Niu H, Wang S, Zhu X, Luo C, Li Y, and Zhao X. (2012). Gene or environment? Species specific control of stomatal density and length. Ecology and Evolution. 2(5): 1065-1070 